\title{
The European Council, the Council and the Member States: changing environmental leadership dynamics in the European Union
}

\section{Rüdiger K.W. Wurzel, Duncan Liefferink \& Maurizio Di Lullo}

To cite this article: Rüdiger K.W. Wurzel, Duncan Liefferink \& Maurizio Di Lullo (2019) The European Council, the Council and the Member States: changing environmental leadership dynamics in the European Union, Environmental Politics, 28:2, 248-270, DOI: 10.1080/09644016.2019.1549783

To link to this article: https://doi.org/10.1080/09644016.2019.1549783

\section{曲 Published online: 17 Jan 2019.}

\section{Submit your article to this journal ๘}

Џ Article views: 381

View Crossmark data ¿

Citing articles: 4 View citing articles 4 


\title{
The European Council, the Council and the Member States: changing environmental leadership dynamics in the European Union
}

\author{
Rüdiger K.W. Wurzel (D) ${ }^{a}$, Duncan Liefferink (iD ${ }^{b}$ and Maurizio Di Lullo (D) $^{c}$ \\ aDepartment of Politics, University of Hull, UK; 'blnstitute for Management Research, \\ Department of Political Sciences of the Environment, Radboud University Nijmegen, The \\ Netherlands; 'Official at the Council of the European Union, Brussels, Belgium
}

\begin{abstract}
The leadership dynamics between the European Council, the Council and the Member States in European Union (EU) environmental policy since the 1970s are analysed. The puzzle is that, although the EU was set up as a 'leaderless Europe', it is widely seen as an environmental leader, albeit sometimes as a one-eyed leader amongst the blind. While differentiating between leadership types, it is argued that the European Council has the largest structural, the Council the most significant entrepreneurial, and the Member States the most important cognitive and exemplary leadership capacities. Most day-to-day environmental policy measures are negotiated by the Environment Council (in collaboration with the European Parliament). The European Council's increased interest in high politics climate change issues is largely due to the EU's global leadership ambitions. Member States have traditionally formed environmental leadership alliances on an ad hoc basis although this may be changing.
\end{abstract}

KEYWORDS European Council; Council; Member States; leaders; leadership types and dynamics; environment

\section{Introduction}

Here, we assess the leadership dynamics between European Union (EU) Member States, the Council of the EU (Council for short) and the European Council in EU environmental policy since the early 1970s. Scholars have paid surprisingly little attention to the Council and European Council - especially considering their central importance for EU (environmental) policymaking and European integration. Even the seminal Environmental Politics special issue, 'A green dimension for the European Community: Political issues and processes' (Judge 1992), lacked an article focusing specifically on any of these actors.

Although the European Council and Council are central actors in EU (environmental) policymaking, they share decision-making powers with other EU, Member State and societal actors. After the Second World War, the founding 
Member States deliberately set up the EU as a 'leaderless Europe' in which decision-making powers are spread among a relatively wide range of actors resulting in 'the European Union deliberately shunning the institution of an overriding leadership' (Hayward 2008, p. 1). At first sight, the EU therefore seems ill-equipped to offer leadership. Nevertheless, scholars have widely portrayed the EU as an environmental leader, albeit sometimes as a one-eyed leader amongst the blind (e.g. Oberthür and Roche Kelly 2010). This creates a puzzle, which we aim to resolve by focusing on the European Council, Council and Member States' abilities to provide leadership. Our contribution answers the following two main research questions: First, which types of leadership have the European Council, Council and Member States offered in EU environmental policy? Second, how have the leadership dynamics developed between these core EU environmental policy actors since the early 1970s?

We argue that EU environmental policy and EU integration are inextricably linked. In the intellectual tug of war between intergovernmentalists and neofunctionalists that initially dominated EU studies, the analytical focus was on whether Member States (intergovernmentalists) or supranational EU institutions (neofunctionalists) dominate the EU policymaking process and European integration. In this important scholarly debate the focus was primarily on who provides leadership rather than on what type of leadership core actors offer. We start with an explanation of the different leadership types, which we then use to analyse the changing roles of the European Council, Council and Member States. In conclusion, we assess the changing leadership dynamics and offer a critical reassessment of our puzzle and the main research questions.

\section{Leaders and leadership}

International relations (IR) scholars (e.g. Young 1991) first recognised the ability of environmental leader states to act as drivers of change before it gained traction in comparative politics and EU policy studies (e.g. Andersen and Liefferink 1997, Liefferink and Andersen 1998). While drawing especially on Burns (1978) and Young (1991), Liefferink and Wurzel (2017) and Wurzel et al. (2017) differentiated between four types of leadership: structural, entrepreneurial, cognitive and exemplary. Here, we draw on these four analytical leadership types while linking them to EU integration theories such as 'old' and 'new' intergovernmentalist approaches (e.g. Hoffmann 1966, Bickerton et al. 2015) and 'old' and 'new' neofunctionalist theories (e.g. Haas 1958, Sandholtz and Stone Sweet 1998).

We argue that structural leadership largely follows the intergovernmentalist logic according to which (the most powerful) Member State actors dominate EU policymaking and European integration. Entrepreneurial leadership is broadly compatible with neofunctionalist reasoning which emphasises the importance of functional cooperation as a means of achieving compromises or, as Young (1999, p. 293) put it, 'negotiating skill to frame issues in ways that foster integrative 
bargaining and to put together deals'. Cognitive leadership closely relates to constructivist approaches (e.g. Hajer 1995, Risse 2009) that emphasise the central importance of ideas for the definition of actors' interests and preferences. Finally, exemplary leadership bears close resemblance to policy transfer and diffusion approaches (e.g. Tews et al. 2003), which both assume that good examples are followed elsewhere. The analytical overlap between our four leadership types structural, entrepreneurial, cognitive and exemplary - and four widely used EU studies theories - intergovernmentalist, neofunctionalist, constructivist and policy transfer theories - is not perfect. However, this does not diminish our core argument that a multifaceted leadership concept, which cuts across wellestablished, rival theories of EU integration and/or policies, can provide novel analytical insights.

First, structural leadership is widely associated with military power, which plays no significant role in resolving EU environmental problems. Importantly, we can also link structural leadership to economic power, e.g. the EU's Single European Market and formal institutional powers (Wurzel et al. 2017, p. 289). Power is important for actors who want to exert structural leadership. However, although '[a]ll leaders are actual or potential power holders, ... not all power holders are leaders' (Burns 1978, p. 19). According to Young (1991, p. 288) 'structural leaders are experts in translating the possession of material resources into bargaining leverage'. Especially, intergovernmentalists view the European Council, bringing together the Member States at the highest political level, as the most powerful EU institution (Hoffmann 1966, Puetter 2014, Bickerton et al. 2015).

Second, entrepreneurial leadership involves the use of diplomatic and negotiating resources, which are needed to broker compromise agreements that offer all parties benefits. An entrepreneurial leader is often 'an agenda setter and popularizer who uses negotiating skill to devise attractive formulas and to broker interests' (Young 1991, p. 300). According to neo-functionalists, Member State officials, interest groups and supranational institutions play a key role in fostering joint solutions to common problems (Haas 1958, Sandholtz and Stone Sweet 1998). As we discuss below, the rotating six-monthly EU Presidency can act as agenda-shaper and facilitate compromise solutions (Tallberg 2006). Importantly, we do not count actions by environmental laggards who try to water down or prevent the adoption of EU environmental measures as entrepreneurial leadership. As Underdal (1994, pp. 178-9) has argued: 'leadership is associated with the collective pursuit of some common good or joint purpose'.

Third, cognitive leadership requires the generation and provision of ideas and expertise that can lead to the re-/definition of actors' interests and preferences (Young 1991, Hajer 1995, Risse 2009). Examples include concepts such as: ecological modernisation, which assumes that ambitious environmental measures are beneficial for both the environment and economy; and the low carbon economy, which aims to reduce greenhouse gas emissions (GHGE) while 
creating jobs in e.g. the renewables industry (Wurzel et al. 2017). Importantly, scientific expertise and experiential knowledge about how new policies or instruments (e.g. emissions trading schemes (ETS)) actually work also constitute cognitive leadership resources (Haverland and Liefferink 2012).

While large Member States tend to have greater structural leadership capabilities than small Member States, the same does not necessarily apply to cognitive environmental leadership capabilities. Denmark, Sweden and the Netherlands have consistently provided important cognitive leadership for EU environmental policy (e.g. Andersen and Liefferink 1997) while, for instance, Belgium has periodically supplied cognitive leadership on climate change issues (Interview, Member State officials, 2016-2017). Liefferink and Wurzel (2017) have argued that in terms of cognitive leadership small Member States may punch well above their structural leadership weight.

Fourth, exemplary leadership (or leadership by example) implies the intentional or unintentional setting of good examples. Intentional exemplary leadership entails the unilateral adoption of ambitious domestic environmental measures, which aim to attract followers. It resembles Grubb and Gupta's (2000) notion of directional leadership. Unintentional exemplary leaders (or pioneers, see Liefferink and Wurzel 2017), however, do not usually try to attract followers although unintentionally they may nevertheless offer models for others. The policy transfer and learning literature contains intentional and unintentional examples that other actors emulate (e.g. Tews et al. 2003).

Different leadership types are usually combined. For example, an actor may facilitate coalition-building (entrepreneurial leadership), provide scientific expertise (cognitive leadership) and set an example (exemplary leadership). According to the state-centred leadership literature, the specific mix of different leadership types that particular actors employ varies across issues and over time (Liefferink and Wurzel 2017). Usually more than one type of leadership is necessary to achieve integrative institutional bargaining success in environmental policy (Young 1991). In other words, structural leadership on its own will not always win the day. Here, we assess whether this applies also to the European Council and Council.

\section{European Council}

For new intergovernmentalists, 'the European Council has established itself as a pivotal institutional actor' (Puetter 2015, p. 165). Dupont and Oberthür (2017, p. 66) have argued that the European Council and Council 'are simultaneously meeting places for Member States (at Ministerial level in the Council and at the level of heads of state or government in the European Council), and [EU] institutions in their own right, which decide on internal and external [EU] negotiation positions' (similarly, see Hayes-Renshaw and Wallace 2006). 


\section{Composition}

The European Council consists of Member States' most senior political representatives, i.e. the Heads of State or Government. The President of the European Commission also attends their meetings while the Foreign Ministers did so until 2009. Prior to the 2009 Lisbon Treaty, the six-monthly rotating EU Presidency chaired all European Council and Council meetings. Since 2009, the European Council has a President who is elected through qualified majority voting (QMV) by the Heads of State or Government. While the European Council's composition has varied over time, it has always been only the Heads of State or Government who take decisions, normally by consensus.

\section{Types of leadership}

Although observers widely see the European Council as the most senior and powerful EU institution (Hayes-Renshaw and Wallace 2006, Puetter 2014), it does not have law-making competences. Instead, it is the Council that, together with the European Parliament (EP), adopts EU laws. According to the 2009 Lisbon Treaty (article 15), the 'European Council shall provide the Union with the necessary impetus for its development and shall define the general political directions and priorities thereof. It shall not exercise legislative functions'.

The European Council became a formal EU institution only with the 2009 Lisbon Treaty. However, already before 2009, the Heads of State or Government acted 'as arbiters of last resort in Council decision-making, as an informal but continuous body, governed not by the treaties but by its own rules of procedure' (Janning 2005, p. 825). Meetings by the Heads of State or Government were initially referred to as summits; they became institutionalised only in 1974 following a Franco-German initiative. However, while the 'Franco-German duumvirate' (Paterson 2012) has, in line with intergovernmentalist logic, long played a central role for the deepening of European integration, it has remained inconsequential for EU environmental policy because France and Germany have different environmental priorities, instruments and regulatory styles (Héritier et al. 1996).

Its internal and external powers provide the European Council with considerable structural leadership capabilities which, however, it has only periodically activated for environmental policy. Examples include the European Council's involvement shortly before and/or after important international environmental meetings. For example, in October 1972, a European summit gave the green light for a common EU environmental policy after the June 1972 UN Stockholm conference had exposed its absence (Bungarten 1978, Judge 1992). It was only the 1987 Single European Act (SEA) that introduced explicit Treaty-based EU environmental policy competences. However, the European Council did not restrain the Council from adopting (in consultation with the EP) a large number 
of EU environmental laws before 1987 (see Figure 1). Other Treaty provisions, e.g. the harmonisation of Member State laws to create a common market, offered the legal basis for it. Over the years, the European Council endorsed the strengthening of environmental provisions in, for example, the 1997 Amsterdam Treaty, which stipulated the principles of sustainable development and environmental policy integration (EPI). By supporting the elevation to Treaty level of such action-guiding norms, the European Council merely played catch-up with the Environment Council which had already accepted them.

By mid-2018, the European Council had not acted as a supreme arbiter for unresolved disagreements on environmental dossiers in the Council with the exception of some climate change dossiers (Interviews, 2017-2018). During the 2020 climate and energy package negotiations, insurmountable differences emerged between the poorer ('new') Central and Eastern European States (CEES) and the richer ('old') Western European Member States (Interviews, EU and Member States officials, 2016-2017). Functional integration and problem-solving had reached its limits at the Council level. With the legislative codecision procedure ongoing between the Council and the EP, the European Council agreed detailed compromise solutions in December 2008. The European Council asked the Council to integrate its proposed compromises in negotiations with the EP. The European Council, being the most senior EU institution, thus used its structural leadership capacity by, on this high politics issue, de facto taking away the Council's prerogative to conduct legislative negotiations with the EP.

For the 2015 UN Paris Climate Conference, all Parties had to submit their future emission reduction plans - Intended Nationally Determined Contributions (INDCs) - in 2014. Since these plans encompassed elements cutting across several policy areas and again pitted the CEES against the Western European Member States, the European Council decided to take a stance in October 2014 while producing a detailed plan (with a 2030 time horizon) to be presented in Paris (Council 2008, 2009, p. 8). The European Council's structural leadership capacity enabled it to draft this plan, which contained elements that would later form the basis of the Commission's legislative proposals. Although traditionally the Commission jealously guards its formal right of initiative, it broadly accepted the European Council's plan. This enabled the Commission to submit proposals, confident of the plan's acceptability to the Council since the European Council had already reached agreement on the headline targets and basic principles.

These examples provide empirical evidence for new intergovernmentalists' claims that the European Council is becoming more involved in detailed policymaking thus triggering 'integration without supranationalism' (Bickerton et al. 2015). One senior Member State official (Interview, 2017) cautioned that the European Council's regular involvement in (high politics) climate change issues is unlikely to continue 
because they [i.e. the Heads of State or Government] have other political issues to deal with, including Brexit. Second, what they have done in the October 2015 deal is probably the level of specificity which they could have done and it becomes more technical on emissions trading and other issues... And you need quite a long time to prepare for that.

However, when the EU revises upwards the 2030 climate change targets and establishes the 2040 targets, the European Council is likely to be involved again. As long as significant differences in GDP and/or energy mixes between Member States remain, the European Council may well be called upon again to mediate conflicts that have remained unresolved at Council level.

EU environmental/climate policy often has a highly technical, scientific character, and thus requires cognitive leadership capacity that is more readily available in the Council than the European Council. The so-called Leaders' Agenda (European Council 2017, p. 2), which the European Council adopted in October 2017 to identify core agenda items for its meetings between October 2017 and March 2019, merely listed climate change (as the only environmental issue) for possible discussions at one of its forthcoming meetings. However, there is an 'agreement that each and every Head of State or Government, if he or she feels left behind, could call a follow-up' (Interview, Member State official, 2017). Accordingly, Member States can request a followup during European Council meetings of issues that the Council had already decided. On climate and energy issues, Member States have derived this 'procedural right' from the Conclusions of the European Council (2014, p. 1) meeting of October 2014 which state: 'The European Council will keep all the elements of the framework under review and will continue to give strategic orientations as appropriate, notably in respect to consensus on ETS, non-ETS, interconnections and energy efficiency'. This statement was itself the result of an informal promise that no Member State should be left behind, which the French President, Nicolas Sarkozy, had made during the 2020 climate and energy package negotiations. However, by mid-2018 this procedure was rarely used with only the Polish government calling for a European Council follow-up regarding the revision of the EU ETS by the Council (and EP) in late 2017.

The European Council's entrepreneurial leadership became apparent, for example, at its 2003 Thessaloniki meeting which set up the Green Diplomacy Network (GDN) in order to strengthen the EU's foreign environmental policy (Council 2003). The GDN and European External Action Service (EEAS), which became operational in 2003 and 2011, respectively, have increased the EU's entrepreneurial leadership capacity. The same applies to the increase in the number of the European Council's meetings since the 2000s and the elected President who the Council Secretariat supports in his/her task to prepare meetings; these developments ensure continuity and facilitate consensus within the European Council (Council Secretariat 2017). However, for environmental 
policy the European Council cannot usually match the Council's entrepreneurial leadership capacities.

The European Council has rarely offered cognitive leadership on environmental issues although it has regularly done so on general European integration issues. One exception constitutes the European Council's endorsement of the socalled Cardiff Strategy, which demanded better integration of environmental concerns by all Council formations; a meeting in Cardiff under the 1998 UK EU Presidency adopted the strategy, which soon ran out of steam (Wurzel 2004).

For the international climate change negotiations, the European Council has frequently endorsed the EU's global leadership ambitions through exemplary leadership. This has manifested itself in, for example, the adoption of relatively ambitious GHGE reduction goals and renewable energy targets, the details of which the Council and the EP normally negotiate following a formal Commission proposal.

\section{Council of the European Union}

Legally speaking, there is only one Council of the European Union - referred to as Council of Ministers until 2009 - although the ministers (and their officials) responsible for particular policy areas usually meet separately in different Council formations such as the Agricultural Council and Environment Council, the latter of which is this section's main focus.

\section{Composition}

The ministerial meetings constitute only the tip of the iceberg of the Council machinery, which includes also the Committee of Permanent Representatives (Coreper) and the Council Working Groups (e.g. Hayes-Renshaw and Wallace 2006). As predicted by neofunctionalist theories (e.g. Haas 1958, Sandholtz and Stone Sweet 1998), over time European integration 'spilled over' into new policy areas including environmental policy. By the 1990s, the number of different Council formations increased to more than 20. The European Council curtailed them at ten in 2009. The growing importance of the Environment Council is evident from its increased number of annual meetings, which rose from one (1973-1982), to two (1982-1989) to a minimum of three (since 1989). However, the increasingly important practice of informal trilogues between the Commission, Council and EP, which aim to speed up decision-making, may over time lead to a reduction in Environment Council meetings. In trilogues the Environment Council has no formal role because the Council negotiation team is led by Presidency officials while the Council's mandate is agreed at Coreper level. The 2017 Estonian Presidency was the first in many years to organise only one Environment Council meeting as informal trilogues dealt with many of its dossiers. 
Coreper and Council Working Groups prepare the ministerial meetings, which national officials from the Brussels-based Permanent Representations attend, frequently joined by officials from national Ministries. For neofunctionalists, this type of engrenage (getting caught in the gears) between EU institutional and Member State actors is in line with the Monnet method which aims to bring about deeper political European integration through functional cooperation or 'integration by stealth' (Hayward 2008). Seen from a leadership type perspective, the multi-layered Council machinery with its deep reach into Member State bureaucracies offers significant opportunities for entrepreneurial leadership and, to a lesser degree, cognitive leadership.

Since the creation of the Environment Council in 1973, the Environment Working Group has held three to four meetings weekly. As the international climate change negotiations advanced and the workload on climate-related issues increased significantly for the Council, it established a Working Party (WP) on climate-related issues separate from the Environment Working Group in the 2000s. In 2001, the Council renamed it the WP for International Environmental Issues with several sub-formations including climate change. Since 2001, there have been two WPs, one on internal and one on international environmental issues (Council 1999, 2001). Four expert groups - on further action, mitigation, adaptation and implementation - undertook the preparatory work for the WP for international environment issues (climate change), which the Council reorganised following the 2015 Paris climate conference. In doing so, the Council further increased its entrepreneurial and cognitive leadership capacities.

Until the 2009 Lisbon Treaty, the six-monthly rotating EU Presidency was responsible for chairing all meetings of both the Council and European Council. The 2009 Lisbon Treaty retained the rotating Council Presidency for almost all Council formations but created an elected European Council President. The rotating Presidency must fulfil the following, at times conflicting, five main roles which require, in particular, entrepreneurial leadership: manager and administrator, honest broker, initiator, point of contact (for other EU institutions and Member States), and representative in international negotiations. While the Council Secretariat tends to emphasise the honest broker role, some large Member States (in particular, France and the UK) have stressed the initiator role (Wurzel 2004).

Since the 1980s, most Presidencies have also organised one informal Environment Council meeting. Such meetings, aiming at encouraging frank exchanges, have no formal agenda (Council 2015). They usually discuss broad themes (e.g. ecological industrial policy) that the incumbent Presidency proposes rather than EU legislation and thus provide opportunities for cognitive leadership. 


\section{Types of leadership}

Compared to the European Council, the Council has generally higher entrepreneurial environmental leadership capacities partly due to the existence of Coreper and Council Working Groups which Member State officials attend. Following the neo-functionalist logic, this type of engrenage between EU and national institutional actors can facilitate joint solutions (Haas 1958, Sandholtz and Stone Sweet 1998). The General Secretariat of the Council (Council Secretariat) supports the Council; it is responsible for the organisation of all Council meetings in Brussels, ensures that rules and procedures are followed and acts as a confidential advisor behind the scenes. Presidencies by smaller Member States tend to rely more heavily on the Council Secretariat than large Member States, not least because they have smaller entrepreneurial leadership capacities (e.g. ministerial staff) to cover the wide range of often highly technical EU environmental policy issues.

Prior to the 2009 Lisbon Treaty, the EU reformed the rotating Presidency only incrementally. Arguably, the most important reform was the introduction of the so-called trio Presidency with at least one large Member State forming part of a 'team' of three Member States. This reform bolstered both the entrepreneurial and structural leadership capacities of the Council. As the Presidency (together with the Commission and the EEAS) represents the EU externally, it is seen as beneficial for the EU's interests that trio Presidencies are able to draw on the diplomatic resources and structural powers of large Member States in international negotiations (Interviews, EU and Member State officials, 2014-2017). For the climate policy issue, leaders and lead negotiators were created in the 2000s to allow for continuity beyond the rotating EU Presidencies (Dupont and Oberthür 2017). This reform further contributed to the external leadership capacities of the Council. France, Germany and the UK (i.e. three of the four large Member States) as well as the Commission have usually held the most important among those positions (Interviews, 2013-2017).

If one accepts that authoritative decision-making in the form of the adoption of legally binding acts amounts to structural leadership, then the Council also has (together with the EP) considerable structural leadership powers in EU environmental policy. With a few exceptions in the field of climate and energy policy where the European Council took the lead (see above), the Environment Council is still the arena where Member States negotiate and assert their powers on environmental matters. According to new intergovernmentalists (e.g. Bickerton et al. 2015), there has been a decline in the Council's overall legislative output in the post-Maastricht era (i.e. after 1992). Figure 1 shows a significant drop in the Council's adoption rate of legally binding environmental acts although only since 2009 and with the exception of 2012-2014. 


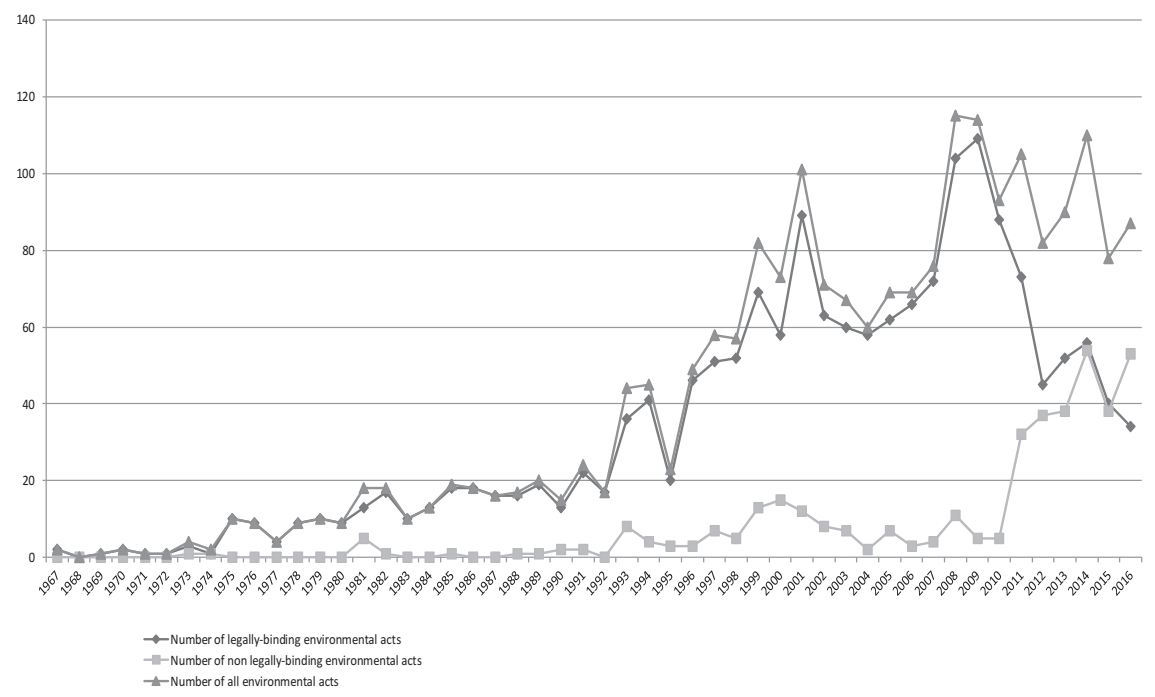

Figure 1. Environmental acts 1967-2016.

Note: Legally binding environmental acts include directives, regulations, decisions and comitology decisions. Non-legally binding environmental acts refer to non-legislative acts including opinions and recommendations. Source: Eur-lex 2017 and Council Secretariat (2017).

Bauer and Knill (2014) have differentiated policy measures according to their density (i.e. number of measures adopted) and intensity (i.e. relative importance of measures). Figure 1 illustrates only the density of legally binding and non-binding measures. Due to word constraints, we focus on adoption trends (policy density).

Figure 1 shows that the 1987 SEA, which introduced explicit environmental Treaty provisions, had no discernible effect on the adoption rate of legally binding environmental acts. Contrary to claims by new intergovernmentalists (Puetter 2014, Bickerton et al. 2015), the ratification crisis of the Maastricht Treaty in 1992, which resulted in the adoption of the subsidiarity principle (according to which decisions should be taken at the lowest possible level), did not trigger a decline in the adoption rate of legally binding environmental acts; on the contrary, it actually rose significantly with the exception of 1995. Yet, the Lisbon Treaty's entry into force in 2009 seems to have triggered a significant downturn in the adoption of legally binding environmental acts. However, other factors have also played an important role including the economic crisis, the Commission's better regulation agenda and its Regulatory Fitness and Performance (REFIT) programme and the maturation of EU environmental policy (Interviews, EU officials, 2016-2017, see also Zito et al. 2019 - this volume $)^{1}$. 
The Council's cognitive leadership capacity appears less significant than its entrepreneurial and structural leadership capacities although there are exceptions. Following the rejection of the draft EU Constitution in referendums in the Netherlands and France in 2005, Ministers represented in the Council identified the environment in general and climate change in particular as 'a new raison d'être' for the EU (e.g. Miliband 2006). The use of an environmental public discourse to gain support for the EU chimes well with cognitive leadership accounts and constructivist accounts (Hajer 1995, Risse 2009). However, not all Member States have been equally convinced of the need for ambitious EU environmental policies and/or deeper European integration. Following the EU's Eastern enlargements in the 2000s, a cognitive East-West divide has opened up on EU environmental policy issues, which changed significantly the actor dynamics in the Council (and European Council). While the 1995 enlargement of the EU by Austria, Finland and Sweden strengthened the Council's environmental credentials, the opposite seems to have happened after the Eastern enlargement in the 2000s. Especially, the poorer CEES have often perceived ambitious EU environmental policy measures as a threat to their economic development (Skjærseth 2018). As Braun (2014, p. 457) has pointed out, in the CEES ' $t$ t]here is a general disbelief in the possibility of the [EU's] climate change policy being an opportunity for business and for jobs'.

Functionally differentiated Council formations avoid grand-scale zerosum games where the winner takes all. However, sectoral differentiation can lead to disjointed decision-making, which is unable to take into account the holistic requirements of cross-cutting policies such as environmental policy (Wurzel 2004). From a cognitive leadership perspective there is therefore a tension between the neofunctionalist EU integration logic, which favours different Council formations along functional lines that help to avoid politically divisive conflicts, and an EPI logic, which enables the integration of environmental requirements by Council formations other than the Environment Council. EPI efforts in the form of Joint Councils in which the Environment Council met, for example, with the Energy Council, flourished briefly in the 1990s. The UK's 1992 EU Presidency launched the Cardiff strategy according to which all nonEnvironment Council formations had to assess how they could integrate environmental requirements into their dossiers. However, by the early 2010s, the Cardiff strategy was 'as dead as a dodo' (Interview, UK official, 2012). So far, the functionalist integration logic has largely triumphed over the EPI logic.

Broadly speaking, the Council has endorsed exemplary environmental leadership more often than the European Council but less often than some 
environmental leader states (or the EP). For example, in 2008, the Council and EP adopted an EU law, which expanded the EU ETS to the aviation sector including non-EU airlines. However, following fierce lobbying of Member States - particularly France, Germany and the UK - by the USA and China, the EU put it on ice (Wurzel et al. 2017, p. 288).

\section{Member States}

Compared to the smaller Member States, the large EU Member States have greater structural power and thus potentially also greater structural environmental leadership capacities. While France, Germany, Italy and the UK participate directly in G7 and G20 meetings, which started to discuss environmental issues more regularly in the 2000s, the smaller Member States receive representation only indirectly through the President of the European Council and the Commission President who defend the EU's collective interests. However, only Germany and the UK have regularly pushed environmental issues - most of all climate issues - at G7/G20 meetings.

Permanent environmental leader coalitions have traditionally not existed at EU level. Instead, coalitions between Member States 'have to be formed on an issue-by-issue basis and remain liable to defection' (Liefferink and Andersen 1998, p. 262). Officials widely see flexible alliances between Member States as more easily facilitating compromise solutions in the Council than permanent or semi-permanent coalitions (Interviews, EU and Member States officials, 2015-2017). However, the cognitive EastWest divide on environmental issues, which emerged after the EU enlargements in the 2000s, is arguably starting to have an impact on alliance building.

\section{Member State alliances}

Following Denmark's 1973 EU accession, most observers identified a 'green trio': Denmark, Germany and the Netherlands (e.g. Andersen and Liefferink 1997). The green trio extended to a 'green sextet' when Austria, Finland and Sweden joined the EU in 1995 (Liefferink and Andersen 1998). However, the EU's environmental leader states exhibit different national environmental regulatory styles, instruments and strategies (Héritier et al. 1996), which helps explain why neither the 'green trio' nor the 'green sextet' ever developed into a semi-permanent, let alone permanent, alliance. Nevertheless, within the Council these 'green' Member States have worked closely on specific environmental issues. In terms of structural leadership, these three/ six Member States did not muster the necessary votes for QMV decisions. Therefore, we cannot explain their significant influence on EU 
environmental policy merely with reference to structural leadership, which would be in line with new intergovernmentalist explanations (e.g. Bickerton et al. 2015). In other words, structural leadership does not necessarily always trump other types of leadership. Instead, the 'green' Member States largely facilitated the adoption of EU environmental policies at a relatively high level of environmental protection through entrepreneurial leadership and especially by providing ideas, expertise and 'good examples', i.e. cognitive and exemplary leadership (Liefferink and Andersen 1998). Well-developed national knowledge infrastructures (e.g. research institutes) and relevant expertise facilitated their efforts (Haverland and Liefferink 2012).

In several cases, the 'green' Member States and/or other Member States provided exemplary leadership by setting 'good examples' which stimulated policy transfer. Frustrated by the Council's inability to adopt the Commission's 1992 proposal for a carbon dioxide/energy tax (due to the UK's veto of supranational taxes on sovereignty grounds), a group of like-minded countries held meetings between officials and Ministers from Environment and Finance Ministries between 1994 and 1998 who discussed the design and effect of national eco-taxes. Belgium, Denmark, Finland, France, Germany, Italy and Sweden participated in the last meetings of this informal group. The UK, which around that time adopted a significant number of national eco-taxes, also attended some meetings (Wurzel et al. 2013, p. 167).

Since the 1990s, environmental leader coalitions have frequently excluded one or several 'green sextet' members while including other Member States such as the UK, especially on climate issues. Following the EU's Eastern enlargements in the 2000s, a relatively stark East-West divide has emerged on EU environmental issues in general and climate change issues in particular. The CEES' comparatively low GDP levels, specific energy mixes (e.g. Poland's high dependency on coal and reliance on Russian gas) and scepticism towards concepts such as ecological modernisation and the low carbon economy help to explain this divide (e.g. Braun 2014, Skjærseth 2018). The CEES seem to have broken with the long established informal tradition that permanent alliances between Member States should be avoided in the (Environmental) Council because they can be counter-productive for finding compromise solutions (Interviews, Member State officials, 2016-2017). The Visegrad Group - Hungary, Poland, Czech Republic and Slovakia - is a relatively small, homogenous alliance with regular meetings chaired by fixed-term presidencies. It has held meetings on climate and energy issues with the aim of defending the group's interests at the EU level. The Visegrad Group wants to progress more slowly towards full decarbonisation than other Member States, which ought to take on a bigger share in the EU's collective GHGE reduction targets. Over time, the Visegrad Group tried to expand its reach to other 
countries (including Bulgaria and Romania) and invited newly acceded Croatia as an observer; this, however, has made the group less homogenous.

Partly in reaction to the Visegrad Group's climate activities, the UK initiated the Green Growth Group (GGG) in 2016 (Interviews, EU and Member State officials, 2015-2017). The GGG is a fairly large, loose alliance with a small secretariat. ${ }^{2}$ As one Member State official explained (Interview, 2017), the 'Visegrad [group] is much more institutionalised, that is clear. Why is the Green Growth Group not more institutionalised? Because there is a fine line between leadership by a group of countries ... and getting everybody on board'. The GGG, which promotes ambitious climate and energy targets while arguing that they can promote economic growth, stages annual ministerial meetings, stakeholder meetings and thematic workshops. The GGG's ministers also hold informal meetings in the margins of the Environment Council where, however, they do not act on behalf of the group. The GGG has provided cognitive and exemplary leadership by, for example, showcasing existing national 'green growth' measures and by promoting more ambitious supranational and international climate targets. The GGG has tried to enlist the help of the EP, thus also exhibiting entrepreneurial leadership.

In 2003, the Member States set up the Green Development Network (GDN) which is meant to integrate environmental objectives into the EU's foreign policy. On climate change, the Foreign Ministries of Germany and the UK as well as France engaged in coordinated outreach activities in the run up to the 2015 UN Paris climate conference (Interviews, 2015-2017). The EEAS did not coordinate these activities, which rely mainly on cognitive and exemplary leadership; EEAS has tried - with various levels of success - to 'keep the flock of $28 \mathrm{EU}$ sheep together' (Interview, EEAS official, 2013) on EU foreign environmental policy issues. The EEAS did however coordinate a Climate Diplomacy Day with outreach climaterelated activities by its staff in about 60 countries.

\section{Conclusion: leadership types and dynamics}

Table 1 provides a summary overview of our four leadership types and how the European Council, Council and Member States have predominantly used them. It also explains briefly the core roles that the European Council, Council and Member States have played on environmental issues at different governance levels. Here, we assess Member States' different types of leadership on the state/sub-state level only if they have a direct impact on the European Council and/or Council or on alliances between Member States. 


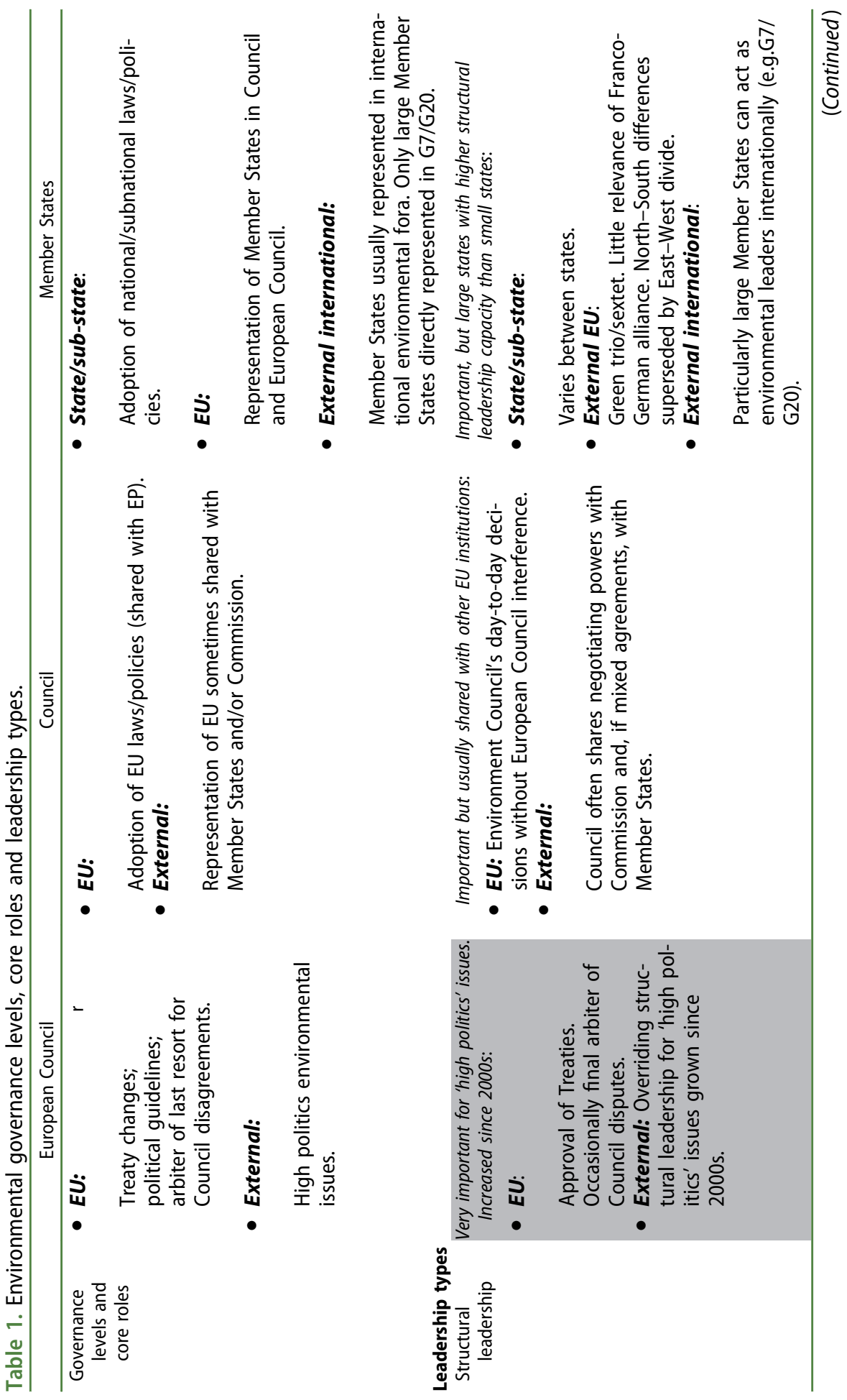




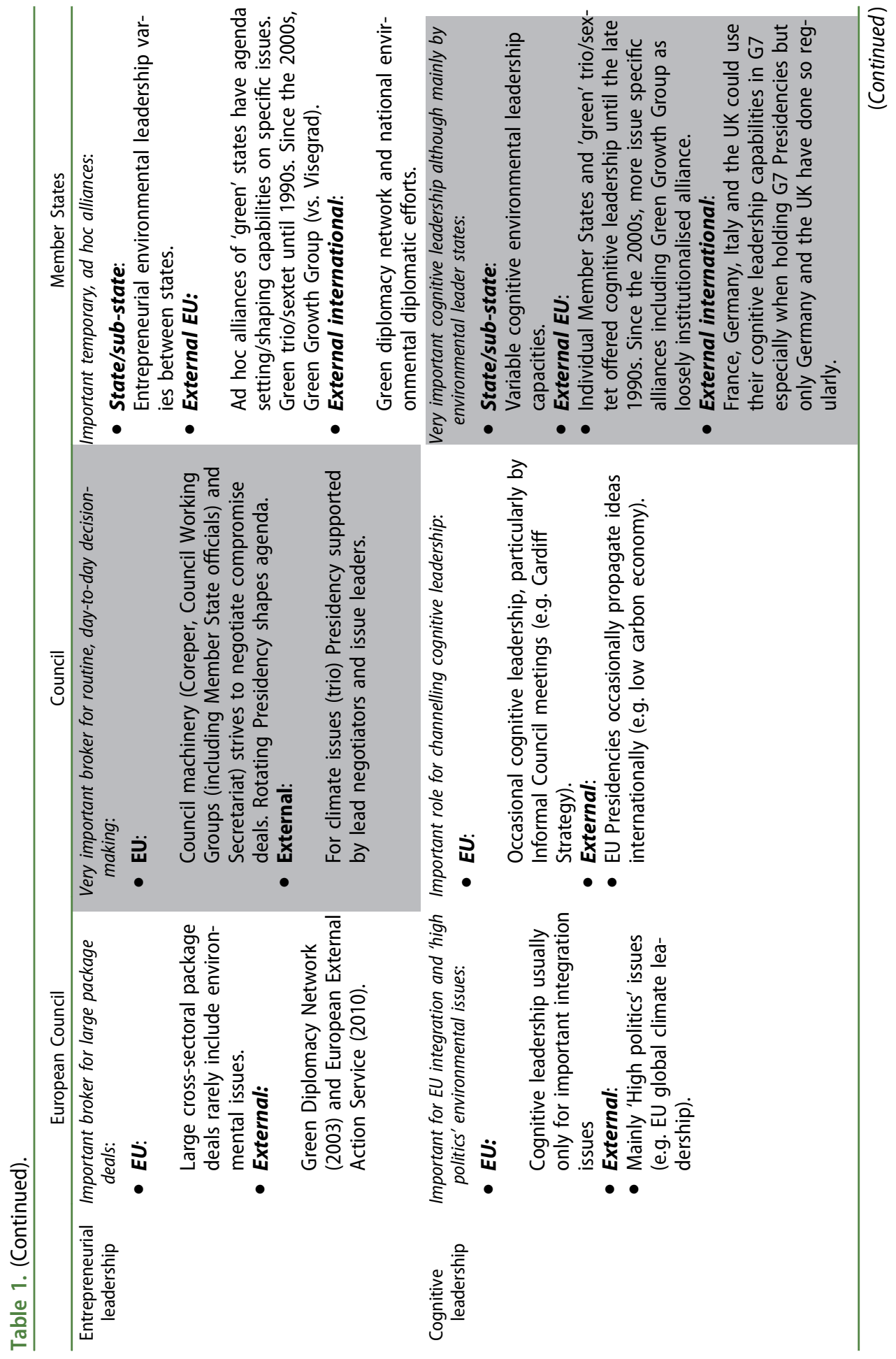




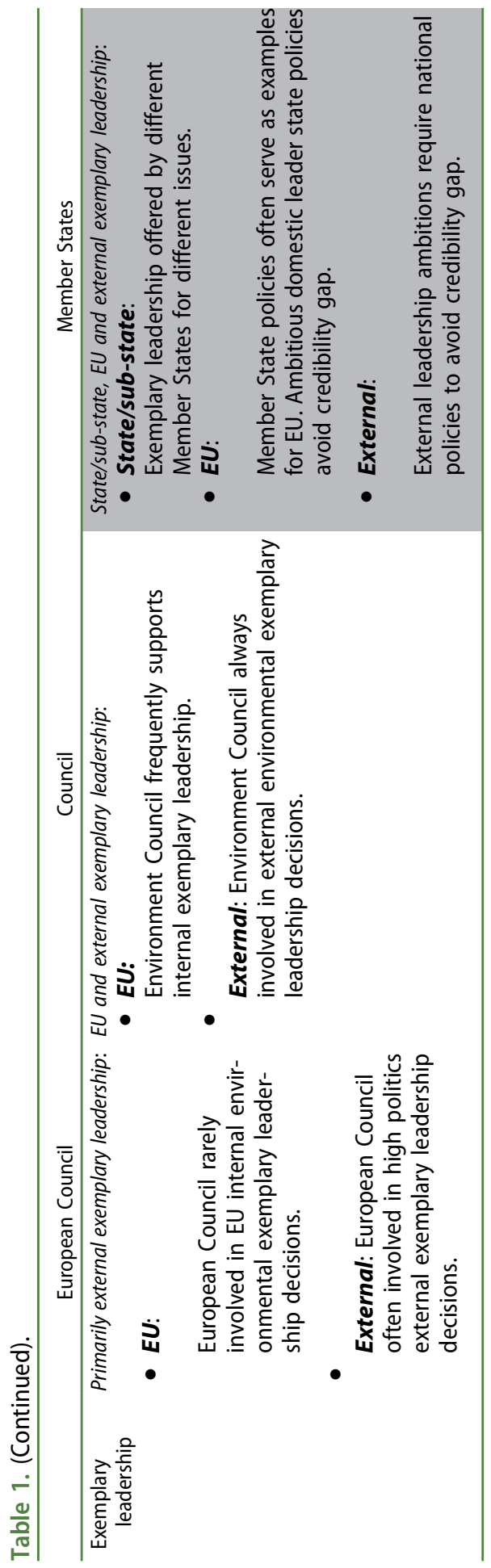


Based on our analytical framework and empirical findings, we have argued that for EU environmental policy, broadly speaking the European Council has the largest structural leadership capacity, the Council has the most significant entrepreneurial leadership capacity and the Member States have the most important cognitive and exemplary leadership capacities (see grey shaded boxes in Table 1).

Over time, the leadership dynamics between the European Council, Council and Member States have evolved. The European Council gave the starting signal for a common environmental policy in the early 1970s (Bungarten 1978) and has taken a close interest in high politics climate change issues since the 2000s (Dupont and Oberthür 2017). Generally speaking, the Council has however dealt with day-to-day EU environmental policy decisions without much interference from the European Council. We were able to find only two examples of EU environmental policy (both of which relate to high politics climate change issues) since the early 1970s that support the claim by new intergovernmentalists (Bickerton et al. 2015) that the European Council is acting as arbiter for disagreements at Council.

New intergovernmentalists are correct in arguing that a decline in EU legislation has taken place although, contrary to their view, for EU environmental policy it did not set in in the post-Maastricht period (i.e. shortly after 1992) but has occurred only since 2008. One important reason for this is that the Council's entrepreneurial leadership capacity has enabled it (together with the EP) to carry on adopting a significant number of legally binding EU environmental laws until the wider political context changed significantly due to the economic crisis, the constitutional crisis surrounding the adoption of the 2009 Lisbon Treaty and the Commission's better regulation initiatives and REFIT programmes.

Since the EU's Eastern enlargements in the 2000s, significant differences in cognitive and exemplary leadership have emerged between the more affluent 'green' Member States and the poorer CEES. The Visegrad Group and, although to a lesser degree, the GGG have become relatively wellinstitutionalised alliances; they could change significantly the leadership dynamics in the Council and the European Council. The emergence of such alliances could herald a departure from the long established tradition that semi-permanent leader alliances should not form because they hinder the search for compromise solutions. It is for this reason that, so far, the GGG has purposefully avoided the further institutionalisation of the group.

For external EU environmental policy, the Council has to share negotiating powers with the Member States (and sometimes also the Commission). In any case, most international environmental agreements constitute so-called mixed agreements which both the EU and Member States sign (Vogler 1999). Attempts by the EEAS to coordinate EU and 
Member State environmental foreign policies have had limited success despite the creation of the GDN in 2003. While the large Member States are directly represented in major non-environmental international settings, e.g. the G7/G20, which have started to discuss more regularly environmental issues, the smaller Member States are only indirectly represented through the President of the European Council and the Commission President. This grants greater structural leadership capacities to the larger Member States although only Germany and the UK have regularly used their G7 Presidencies to push environmental issues. However, in terms of cognitive and exemplary leadership, some of the smaller Member States have been capable of punching well above their structural leadership weight; this explains why they have been relatively successful in influencing EU environmental policy (Liefferink and Andersen 1998). Brexit is likely to lead to efforts among the remaining Member States to use other leadership types to compensate for the EU's reduced structural environmental leadership capacities resulting from Britain's exit.

The simultaneous use of different leadership types is usually required for successful environmental policymaking. This helps explain the mutual dependency between the European Council, Council and Member States in EU environmental policymaking. This dependency becomes most apparent in the EU's external environmental policy, notably in international climate negotiations. For instance, before and during the 2009 Copenhagen and 2015 Paris climate conferences, the European Council, Council and Member States combined different types of leadership, without much success in Copenhagen but with considerable success in Paris (Wurzel et al. 2017). EU actors have used the EU's relatively ambitious GHGE reduction and renewable energy targets (exemplary leadership), framing of climate change as both a threat to the environment and an opportunity for the low carbon economy (cognitive leadership), facilitation of alliances of states in favour of relatively ambitious climate policy measures (entrepreneurial leadership) and economic power (structural leadership) to accomplish a reduction of the 'credibility gap' (Dupont and Oberthür 2017) between the EU's external ambitions and its domestic actions.

Differentiating between different types of leadership, while taking into account the changing leadership dynamics between the European Council, Council and Member States, helps to resolve at least partly the puzzle that although the EU was set up as a 'leaderless Europe' observers have widely seen it as an environmental leader. We linked the different types of leadership in our fourfold leadership typology to existing EU integration theories. While a new intergovernmentalist perspective helps to explain the increased structural leadership offered by the European Council on high politics climate change issues, the neofunctionalist logic elucidates the interlocking 
relations (or engrenage) between EU institutional and Member State officials which also fit well an entrepreneurial leadership perspective. Constructivist approaches explain well Member States' cognitive leadership while we find many examples of exemplary leadership in the policy transfer literature.

\section{Notes}

1. The EP nearing the end of its legislative term and Member States' reluctance to agree to EU legislation shortly before national elections can also cause moderate, temporal fluctuations.

2. Belgium, Germany, Denmark, Spain, Estonia, Finland, France, Ireland, Italy, Luxembourg, the Netherlands, Portugal, Sweden, Slovenia, United Kingdom and Norway as well as the Commission have regularly attended GGG meetings. Austria has been recently asked to attend.

\section{Acknowledgments}

The authors are grateful to the referees and editors for their helpful comments on earlier drafts. The usual disclaimer applies. The authors conducted more than 20 interviews with EU and Member States officials in 2003-2004 and 2012-2017. The institutional affiliations of the interviewees are not stated to ensure non-attributability.

\section{Disclosure statement}

No potential conflict of interest was reported by the authors. The views expressed by Maurizio di Lullo are his personal views and not those of the Council of the EU.

\section{Funding}

Rudi Wurzel thanks the British Academy (grant SG 131240) and University of Hull for funding.

\section{ORCID}

Rüdiger K.W. Wurzel (D) http://orcid.org/0000-0001-5873-4232

Duncan Liefferink (D) http://orcid.org/0000-0002-3594-3274

Maurizio Di Lullo (D) http://orcid.org/0000-0001-9508-1859

\section{References}

Andersen, M.S. and Liefferink, D., eds., 1997. European environmental policy: the pioneers. Manchester: Manchester University Press.

Bauer, M.W. and Knill, C., 2014. A conceptual framework for the comparative analysis of policy change. Journal of European Public Policy, 16 (1), 28-44. 
Bickerton, C.J., Hodson, D., and Puetter, U., 2015. The new intergovernmentalism. Oxford: Oxford University Press.

Braun, M., 2014. EU climate norms in East-Central Europe. Journal of Common Market Studies, 52 (3), 445-460. doi:10.1111/jcms.2014.52.issue-3

Bungarten, H.H., 1978. Umweltpolitik in Westeuropa. Bonn: Europa Union Verlag. Burns, J.M., 1978. Leadership. New York: Harper \& Row.

Council, 1999. List of committees and working parties. Brussels: General Secretariat of the Council, 13406/99.

Council, 2001. List of committees and working parties. Brussels: General Secretariat of the Council, 10279/01.

Council, 2003. Thessaloniki European Council 19 and 20 June. Presidency conclusions. Brussels: General Secretariat of the Council, 11638/03.

Council, 2008. Energy and climate change - elements of the final compromise 17215/ 08. Brussels: General Secretariat of the Council.

Council, 2009. Brussels European Council. 11 and 12 December 2008. Brussels: General Secretariat of the Council, 17271/08.

Council, 2015. Handbook of the Presidency of the Council of the European Union. Luxembourg: General Secretariat of the Council of the EU.

Council Secretariat, 2017. The president's role. Available from: http://www.consi lium.europa.eu/en/european-council/president/role/ [Accessed 14 November 2017].

Dupont, C. and Oberthür, S., 2017. The Council and the European Council. In: R. Wurzel, J. Connelly, and D. Liefferink, eds. The European Union in international climate change politics. London: Routledge, 66-79.

European Council, 2014. Conclusions. EUCO 169/14. Brussels: General Secretariat of the Council.

European Council, 2017. Leaders' agenda. Building a future together. Brussels: European Council.

Grubb, M. and Gupta, J., 2000. Leadership. In: J. Gupta and M. Grubb, eds. Climate change and European leadership. Dordrecht: Kluwer, 15-24.

Haas, E.B., 1958. The uniting of Europe. Stanford, CA: Stanford University Press.

Hajer, M., 1995. The politics of environmental discourse. Oxford: Clarendon.

Haverland, M. and Liefferink, D., 2012. Member state interest articulation in the Commission phase. Journal of European Public Policy, 19 (2), 179-197. doi:10.1080/13501763.2011.609716

Hayes-Renshaw, F. and Wallace, H., 2006. The council of ministers. 2nd ed. Basingstoke: Palgrave Macmillan.

Hayward, J., ed., 2008. Leaderless Europe. Oxford: Oxford University Press.

Héritier, A., Knill, C., and Mingers, S., 1996. Ringing the changes in Europe. Berlin: de Gruyter.

Hoffmann, S., 1966. Obstinate or obsolete? The fate of the nation-state and the case of Western Europe. Daedalus, 68 (3), 862-915.

Janning, J., 2005. Leadership coalitions and change: the role of states in the European Union. International Affairs, 81 (4), 821-833. doi:10.1111/j.14682346.2005.00486.x

Judge, D., ed., 1992. Special issue. A green dimension for the European community: political issues and processes. Environmental Politics, 1 (4), 1-249. doi:10.1080/ 09644019208414043 
Liefferink, D. and Andersen, M.S., 1998. Strategies of the 'green' member states in EU environmental policy-making. Journal of European Public Policy, 5 (2), 254-270. doi:10.1080/135017698343974

Liefferink, D. and Wurzel, R.K.W., 2017. Environmental leaders and pioneers: agents of change? Journal of European Public Policy, 24 (7), 951-968. doi:10.1080/13501763.2016.1161657

Miliband, D., 2006. Building an environmental union. Speech in Berlin, 19 September. Berlin: British Embassy Berlin.

Oberthür, S. and Roche Kelly, C., 2010. EU leadership in international climate policy: achievements and challenges. The International Spectator, 43 (2), 35-50. doi:10.1080/03932720802280594

Paterson, W., 2012. A contested Franco-German duumvirat. In: J. Hayward and R. Wurzel, eds. European disunion. Basingstoke: Palgrave Macmillan, 236-251.

Puetter, U., 2014. The Council and the European Council. Oxford: Oxford University Press.

Puetter, U., 2015. The European Council. In: C.J. Bickerton, D. Hodson, and U. Puetter, eds. The new intergovernmentalism. Oxford: Oxford University Press, 165-184.

Risse, T., 2009. Social constructivism and European integration. In: A. Wiener and T. Diez, eds. European integration theory. Oxford: Oxford University Press, 144-160.

Sandholtz, W. and Stone Sweet, A., 1998. European integration and supranational governance. Oxford: Oxford University Press.

Skjærseth, J.B., 2018. Implementing EU climate and energy policies in Poland. Environmental Politics, 27 (3), 498-518. doi:10.1080/09644016.2018.1429046

Tallberg, J., 2006. Leadership and negotiation in the European Union. Cambridge: Cambridge University Press.

Tews, K., Busch, P.-O., and Jörgens, H., 2003. The diffusion of new environmental policy instruments. European Journal of Political Research, 42 (4), 569-600. doi:10.1111/1475-6765.00096

Underdal, A., 1994. Leadership theory. In: I.W. Zartman, ed. International multilateral negotiation. San Francisco: Jossey-Bass, 178-197.

Vogler, J., 1999. The European Union as an actor in international environmental politics. Environmental Politics, 8 (3), 24-48. doi:10.1080/09644019908414478

Wurzel, R.K.W., 2004. The EU presidency: 'Honest broker' or driving seat. London: Anglo-German Foundation. http://www.agf.org.uk/cms/upload/pdfs/R/2004_ R1258_e_eu_presidency.pdf

Wurzel, R.K.W., Connelly, J., and Liefferink, D., eds., 2017. The European Union in international climate change politics. London: Routledge.

Wurzel, R.K.W., Zito, A.R., and Jordan, A., 2013. Environmental governance in Europe. Cheltenham: Edward Elgar.

Young, O.R., 1991. Political leadership and regime formation. International Organisation, 45 (3), 349-375. doi:10.1017/S0020818300033117

Young, O.R., 1999. Regime effectiveness: taking stock. In: O.R. Young, ed. The effectiveness of international environmental regimes. Cambridge, MA: MIT Press, 249-279.

Zito, A.R., Burns, C., and Lenschow, A., 2019. Is the trajectory of European Union environmental policy less certain? Environmental Politics, 28 (2). 